\title{
"Wise Use" in Watarase-yusuichi Creating New Value through the Integration of Stakeholders
}

\author{
Mikiko Sugiura $^{1}$ \\ ${ }^{1}$ Center for Global Education and Discovery, Sophia University, Tokyo, Japan \\ Correspondence: Mikiko Sugiura, Center for Global Education and Discovery, Sophia University, 7-1 Kioi-cho \\ Chiyoda-ku, Tokyo, Japan 102-8554.
}

Received: March 25, 2019

doi:10.11114/ijsss.v7i3.4168
Accepted: April 2, $2019 \quad$ Available online: April 9, 2019

URL: https://doi.org/10.11114/ijsss.v7i3.4168

\begin{abstract}
Watarease-yusuichi, a man-made retarding basin, which has functioned as a flood control for about 100 years, entered a new phase in 2012 as a registered site under the Ramsar Convention. Through diversification of wetland use, despite the complexity of the root of the Convention's "wise use," Watarase-yusuichi represents a unique perspective on sustainable development so that wetlands can continue creating new value for human society. The emerging ecological function as the habitat for endangered fauna and flora exemplifies not only the universal paradigm shift in human involvement in the wetland's use, but also the importance of the integration of stakeholders regarding the issues of wetland management as IRBM (the Integrated River Basin Management), which gives us more holistic perspective on a participatory and comprehensive approach to planning and management. Regarding the integration of stakeholders, despite the significant differences in original ideas on wetland management, it should be noted that five major types of stakeholders, including the local and scholarly communities, collaborated to device a future plan for Watarase-yusuichi through lengthy discussions. The several challenges remain in terms of "wise use" even after the successful designation under the Ramsar Convention. One of the difficulties is how to share a common goal or incentive among groups with different interests. Taking the advantage of wetland's characteristics distinguished from other water-related facilities such as a multi-purpose dam reservoir, regular and innovative action should be taken, such as information dispatch from individuals.
\end{abstract}

Keywords: stakeholder integration, diversified wetland use, wise use, IRBM, active learning

\section{Introduction}

Watarase-yusuichi, that is, the Watarase Retarding Basin, which is a man-made 3,300-hectare wetland located almost in the center of the Kanto Plains, serves as the vital point for flood control of the Tone River System. In terms of its function, it could be described as a floodplain that temporarily retains river overflow from tributaries such as the Omoi River so as not to affect the trunk of the Tone River (Ministry of the Environment, 2015) (Figure 1). Despite the dark side of the development history underlying the water work project, due to the pattern of submerged land being untouched, the retarding basin has come to have an ecological function. This function eventually resulted in its designation as a registered wetland under the Convention on Wetlands of International Importance in 2012, especially as Waterfowl Habitat (hereinafter the Ramsar Convention). The concept of "wise use," which occupies an important place within the framework of the Convention, is now defined in such a way as to emphasize the compatibility between the "wise use" and "ecological character" presented by ecosystems and ecosystem services: "the maintenance of their ecological character, achieved through the implementation of ecosystem approaches, within the context of sustainable development"(Ramsar Convention 2005, 2007).

This paper focuses on the conceptual framework for "wise use" of wetlands in the case of Watarase-yusuichi, examines "wise use" from the perspective of the integration of stakeholders, and analyzes the future possibility to contribute to creating wetland value in comparison with a different type of man-made water infrastructure, the Miyagase Dam, a multi-purpose dam reservoir located on the Kanto Plains. 


\section{Overview of "Wise Use" in History}

\section{1 "Wise Use" as an Enticing Phrase}

It has been often argued that the concept of "wise use" is somewhat challenging. The problem seems to lie in the fact that the "wise use" principle set out in Article 3.1 of the Convention (1971), and its definition and application by the Conference of the Contracting Parties are sometimes referenced elsewhere in a broader context than the one for which it was originally designed, whether intentionally or not. The "wise use movement" is a good example of the ambiguity of the phrase. The movement emerged in North America around the 1980s and 1990s from opposition to the mainstream environmental movement by stressing the importance of stewardship over natural resources and its exploitation by private sectors, which was strategically but unfairly appropriated from the early conservation movement (McCarty, 2002). Due to the confusion with the use of the phrase, the organization of the Ramsar Convention clearly notes that the usage of "wise use" defined by the Ramsar Convention has been established and has evolved completely independently from the so-called wise-use movement (Ramsar Convention, 1993).

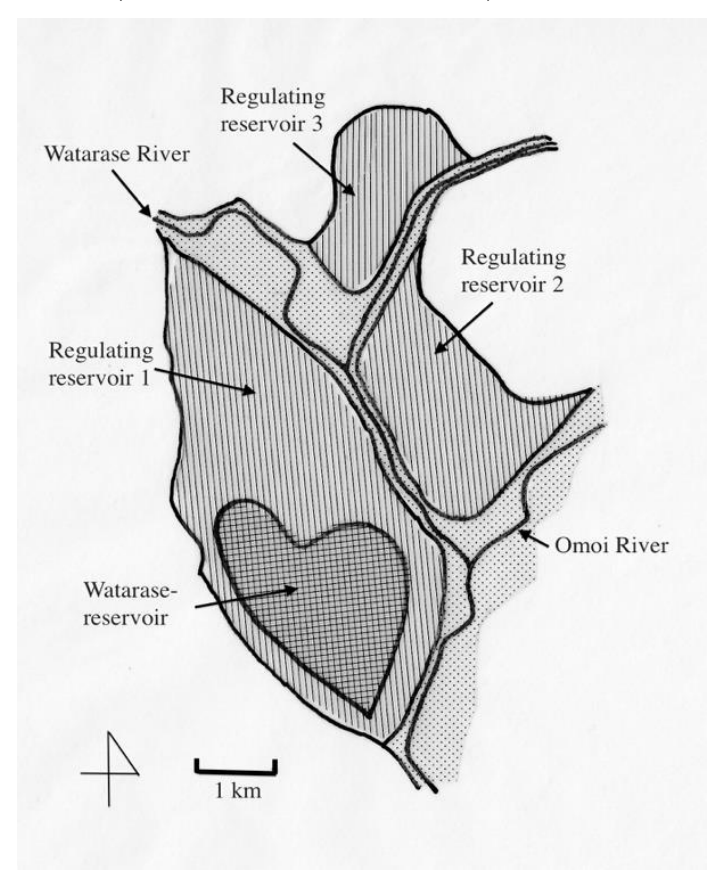

Figure 1. Watarase-yusuichi

Source: By the author

\subsection{Important Facet of Sustainable Society}

The academic community shares the common understanding that Gifford Pinchotused, who was the first practicing forester and politician of the United States who led modern environmentalism as a utilitarian conservationist, was the first person to use the phrase. As he stated, conservation means "the wise use of the earth and its resources for the lasting good of men" (Pinchot, 1998). He also argues "conservation is the foresighted utilization, preservation, and/or renewal of forest, waters, lands, and minerals, for the greatest good of the greatest number for the longest time." Though little mention is made by the Convention on the linkage to Pinchot's usage, it seems right to presume that Ramsar's usage originated from Pinchot's utilitarian perspective or meant the same concept that emphasizes the possible compatibility between human use on a sustainable basis and conservation in general (Ramsar Convention, 2007).

The "wise use" in the Ramsar Convention, should therefore be understood as an originally anthropocentric involvement with the natural environment in such a way as to contribute to sustainability of human society, which came to stress more a biological value in nature as the ecological school gained momentum. The changing ideas on "wise use" observed in the original Convention (Ramsar Convention 1971), the several Annexes of Article 3.1 published afterwards (Ramsar Convention 1990), and the guidance (Ramsar Convention, 1993) exemplify the complexity of the root of the present "wise use." It could be regarded as a pioneering and unique approach from the perspective of sustainable development so that wetlands could continue creating new value for human society.

\subsection{Universal Concept from a Perspective of Conservation}

It should be also noted that the present "wise use" in the Ramsar Convention was clearly presented by Makoto Numata 
more than half century ago as the case of Satoyama, a Japanese traditional lifestyle dependent on forest management and exploitation. He claims that conservation can be achieved through human-caused disturbances in order to stop the vegetation succession at a stage that is favorable for human beings (Numata, 1973). That is, the idea of "wise use," which is based on the compatibility between human use and conservation as far as it can sustain the natural environment, has been widely shared regardless of the difference in topographical conditions, and remains as a core of the principle on the relationship between humans and nature in the context of conservation.

\section{Significance of Stakeholder Integration in Terms of "Wise Use"}

\subsection{Diversified Functions of Wetland Use}

Taking the current understanding of "wise use" in the Ramsar Convention into account, the discussion now turns to what the Watarase-yusuichi, originally a floodplain but now an ecological habitat for endangered fauna and flora with a value-added function, could imply in terms of "wise use." What kind of human involvement should be highlighted for creating a new value of the wetland?

The three functions of the Watarase Retarding Basin are flood control as the first priority, followed by water supply, and ecological habitat. It should be stressed that the last function is relatively new and was not anticipated when the retarding basin was originally constructed around 100 years ago, but was obtained as a value-added function through several unexpected changes. As highlighted by researchers, there are two major factors that contributed to the emerging ecological function. The first is the universal paradigm shift in human involvement in the wetland's use, which is presented by the complex roots of "wise use" under the Ramsar Convention (Sugiura, 2018a), and the second is the integration of stakeholders on the issue of wetland management (Sugiura, 2018b).

\subsection{Insights Drawn from Good Practices in IRBM}

Regarding the integration of stakeholders, the viewpoint of IRBM, which is a participatory and comprehensive approach to planning and management as an integral part of Integrated Water Resources Management (IWRM) (UNESCO, 2009), can provide us with a more holistic viewpoint. IRBM is considered best practice in water resources to integrate water quality and quantity of the river basin as water use becomes more multi-purpose through agriculture, industry, city use, power generation, recreation, and so on. The aim of the IRBM is "to establish a framework for coordination whereby all administrations and stakeholders involved in river basin planning and management can come together to develop an agreed set of policies and strategies such that a balanced and acceptable approach to land, water, and natural resource management can be achieved" (World Bank, 2006). That is, integration of stakeholders plays an important role in water management, which is regarded as one of three factors that should be integrated through IRBM approaches. The first is the old administrative boundaries established by governments that mismatch the hydrologic boundaries of a basin, the second is the three pillars of economy, environment, and society frequently referred to as sustainable development, and the last is the integration of stakeholder and community viewpoints (World Bank, 2006).

In addition, the Ramsar Convention mentions the integration of stakeholders in the context of wetlands planning and management as the good practices of "wise use" to maintain its integrity within the international framework of water resources management: "People who occupy, own, govern, or rely on the wetlands have a natural interest in them. Involve them directly and take their needs into account" (Ramsar Convention, 2015). It must be stated how and to what extent the integration of stakeholders should be examined not only as a significant factor for "wise use," but also as an achievement resulting from such use.

\section{Integration of Stakeholders in the Case of Watarae-yusuichi}

\subsection{Kinds of Actors}

There are five types of major stakeholders that have been involved in wetland planning and management of the current Watarase-yusuichi. First, the local office of the Ministry of Land, Infrastructure, Transport, and Tourism, or "Kanto Regional Development Bureau" (hereinafter MLIT). Second, the General Incorporated Foundation for Watarase-yusuichi Acclimation founded in 1988 under the jurisdiction of MLIT. Third, the Tonegawa Watershed Community Council for Watarase-yusuichi, a civic association established in 1990 comprising local and academic communities. Fourth, the local authorities of four cities and two towns, and lastly the Watarase Mirai Foundation, a civic association established in 2001 with the aim of expanding an environmental study and activity to upstream and downstream areas.

In terms of regional development, the existence of Watarase-yusuichi, a large retarding basin straddling six municipalities, was one barrier to economic regional development due to the difficulty regarding collaborative action (Nagahama, 2012). A sense of stagnation shared among the local authorities in the last decade is regarded as one of the factors that drove the rising ecological movement around the retarding basin as a new driving force beyond its borders, which was believed to be effective to identify new value in local resources as a result of the situation. 


\subsection{Process of "Integration"}

With regard to stakeholder integration, the outline for "the Basic Plan for Wetland Conservation and Restoration of Watarase-yusuichi," a major turning point for Japanese wetlands planning and management, was finally proposed by MLIT in 2010 as the result of interactive discussion among the stakeholders through more than 10 official meetings, six workshops, and a myriad unofficial gatherings between 2002 and 2010 (The editorial committee of Watarase-yusuichi's designation under the Ramsar Convention, 2013).

Table 1 shows the major actions taken by two types of stakeholders, the authority and the civic community, up to 2012 when Watarase-yusuichi was designated as a registered wetland under the Ramsar Convention. Each action appears to have reflected the difference of opinion regarding if the management of Watarase-yusuichi should be development- or ecology-oriented. The former was well represented by a resort development plan proposed in 1988 by the General Incorporated Foundation for Watarase-yusuichi Acclimation (Figure 2), while the latter was proposed by the "Watarase-yusuichi Eco-Museum Plan" (Figure 3) proposed in 1999 as a counter idea to the original resort plan (The editorial committee of Watarase-yusuichi's designation under the Ramsar Convention, 2013; Tonegawa Watershed Community Council for Watarase-yusuichi, 2009).

Table 1. Major actions taken by the authority and the civic community

\begin{tabular}{|c|c|}
\hline YEAR & Civic community's action \\
\hline- & Planning of the $2^{\text {nd }}$ water reservoir \\
\hline 1988 & $\begin{array}{l}\text { "General Incorporated Foundation for Watarase-yusuichi } \\
\text { Acclimation" was established and proposed a resort } \\
\text { development plan }\end{array}$ \\
\hline 1990 & $\begin{array}{l}\text { "Tonegawa Watershed Community Council for } \\
\text { Watarase-yusuichi" was established }\end{array}$ \\
\hline 1997 & The development plan was tentatively suspended by MLIT \\
\hline 1999 & "Watarase-yusuichi Eco-Museum Plan" was proposed \\
\hline 2000 & New eco-oriented concept proposed by MLIT \\
\hline 2001 & Announcement of wetland restoration (2002-) by MLIT \\
\hline 2002 & $\begin{array}{l}\text { "Exploratory Committee for Wetland Conservation and Restoration of Watarase-yusuichi" established, comprising the } \\
\text { Community Council and the Mirai Foundation } \\
\text { The development plan was officially halted }\end{array}$ \\
\hline 2010 & $\begin{array}{l}\text { "Basic Plan for Wetland Conservation and Restoration of Watarase-yusuichi" was proposed by the Exploratory } \\
\text { Committee }\end{array}$ \\
\hline 2012 & Designation as a registered site under the Ramsar Convention \\
\hline
\end{tabular}

Source: created by the author based on the editorial committee of Watarase-yusuichi's designation under the Ramsar Convention (2013) and Tonegawa Watershed Community Council for Watarase-yusuichi (2005)

The turning point for MLIT was their announcement in 2000 of a new eco-oriented concept, which presumably reflected the counter idea proposed by the civic association in 1999.

Economic stagnation, which has been mentioned in the context of regional development, is also regarded as a factor to change the authority's principle of wetlands planning and management. Not only the decrease in development pressure but also the demand in saving administrative cost must have been a factor in the change of the authority's principle in adapting to the universal paradigm shift that could be observed in the second half of the 20th century (Sugiura, 2018a).

The establishment of the "Exploratory Committee for Wetland Conservation and Restoration of Watarase-yusuichi" in 2002 was also remarkable. In addition to the academic community that comprised one third of the committee, the membership varies across public authorities or civic associations such as the Watarase Mirai Foundation, the General Incorporated Foundation for Watarase-yusuichi Acclimation (but only the first meeting), Tonegawa Watershed Community Council for Watarase-yusuichi, the local office of MLIT, and related municipalities.

Considering the fact that the Basic Plan for Wetland Conservation and Restoration of Watarase-yusuichi was proposed by the Exploratory Committee in 2010, only two years before the designation under the Ramsar Convention, it seems right to infer that the collaboration within the Exploratory Committee was very successful; however, the membership has occasionally changed accordingly. After 2012, in addition to the Exploratory Committee, the Monitoring Committee for Wetland Conservation and Restoration of Watarase-yusuichi, and the Working Group of the Exploratory Committee for Wetland Conservation and Restoration of Watarase-yusuichi were also established for further scientific study of ecological habitat and for feedback of the results to society. 


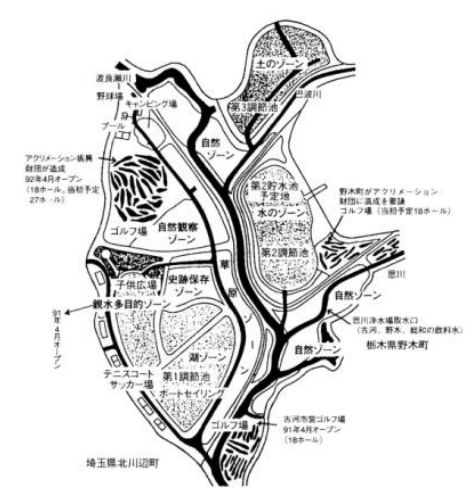

Figure 2. The original resort plan

Source: Tonegawa Watershed Community Council for Watarase-yusuichi (2005)

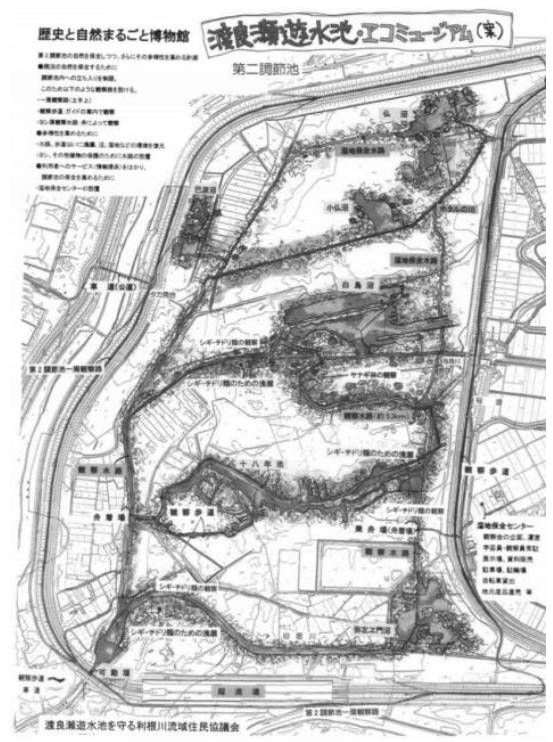

Figure 3. Eco-Museum Plan

Source: The editorial committee of Watarase-yusuichi's designation under the Ramsar Convention (2013)

\section{Discussion}

\subsection{Remaining Issue}

Despite the successful result of the designation under the Ramsar Convention, there are still several challenges for this region in terms of "wise use" of wetlands. One of the difficulties is the sustainability of the group or committee comprising various stakeholders with different interests. That is, how to maintain a strong incentive to collaborate within a unit. The designation under the Ramsar Convention should have worked well as a common goal regardless of stakeholders' status or interests. However, once it has been achieved, it can be easily assumed that the group needs another goal or incentive to maintain the bond for further activity. Although it could be analyzed using the theory of collective action as a general issue of incentives, greater emphasis should be placed on taking advantage of the wetland's characteristics with the phrase "wise use," as stated herein. The case is pioneering and significant in that it contributes to the sustainability of human society on a sustainable basis by creating new value.

\subsection{Advantages as Wetland}

To clarify the wetland's advantages due to the differences from other water-related facilities, the comparison of Watarase-yusuichi with a multi-purpose dam reservoir, the Miyagase Dam also located on the Kanto Plain, must be effective. The Miyagase Dam, one of the largest dam reservoirs located about 50km from the center of Tokyo, was completed in 2001 as a multiple-purpose dam reservoir that mainly contributes to flood control in the Kanto region.

The key common characteristics between the Miyagase Dam and Watarase-yusuichi can be summarized as follows. 
First, they are man-made water infrastructures characterized by three functions, flood control, water supply, and ecological function. In the case of the Miyagase Dam, its ecological contribution is described as "a leisure venue with the function of a natural park within reach of suburban areas" (Miyagase Dam Control Office, 2016). Therefore, regarding the second common characteristic, they are viewed as ecologically effective regardless of their man-made origin. In addition to maintaining environmental flow through dam operation, it is officially stated that the Miyagase Dam contributes ecologically by implementing an afforestation project and a biotope project to restore the environmentally damaged dam site, though it is relatively small in scale (MLIT, 2006). By highlighting the ecological contribution, the Miyagase Dam Control Office aims to demonstrate their understanding of sustainability for the next generation, and to show accountability and transparency as the authority.

On the other hand, although both of them are anthropocentric in the sense that the major purpose of each facility is flood control, the clear difference can be observed in terms of the specific activities available for visitors. Watarase-yusuichi, for example, offers people precious opportunities for nature watching including endangered flora and fauna, environmental study tours such as nature cycling and walks, and open space for recreational use, such as hot-air balloon rides. That is, there appears to be diversified wetland use in Watarase-yusuichi (Sugiura, 2018a). The Miyagase Dam, in contrast but very uniquely, attracts large numbers of site visitors who regularly come to see dam-water discharge, about seven to eight times a month weather permitting. According to the Dam Control office, the total number of site visitors was 100,000 by the end of November in 2017 (Miyagase Dam Control Office, 2016). Several side events are also conducted such as Christmas illuminations between November and December, open days for indoor or outdoor activities such as climbing the dam stairs and visiting a discharge tunnel, sports events such as a marathon, and fireworks. In addition, the natural scenery around the dam reservoir gains considerable popularity in every season. The report, which is regularly uploaded on the home page of the Control Office, contains various content such as wild animals, and the changing seasonal view observed from the reservoir.

Although there is a difference in the type of man-made facilities, the approach of the Miyagase Dam reservoir can also be regarded as an example of diversification in resource use. Comparing the Miyagase's case to eco-tourism in general, which faces the challenge of resource use given the dilemma situation, that is, more tourists will degrade the environment, the Miyagase Dam reservoir successfully uses the resource and diversifies the dam's functions. However, as far as stakeholder involvement is concerned, as a significant factor for "wise use" and the achievement of "wise use," one-way flow of information and event offers demonstrate the limitation of highly man-made infrastructures. Considering the original challenging and unique approach of "wise use," how to involve stakeholders for creating new value should be emphasized in the context of wetland use. That is, regular and innovative action should be taken so that value can be revitalized and new value created for the future through the sustainable involvement of society in wetland use.

\subsection{From Education to Active Learning}

The development from "environmental education" to "active learning" in Watarase-yusuichi illustrates the aforementioned argument well. The latter is an approach, extending the definition of environmental education, that is based on information learning through given devices and opportunities. Smith and Williams (1999) describe the learning process as "developing a citizenry capable of making wise decisions about the impact of human activities on the environment, examining and altering fundamental cultural beliefs and practices that are contributing to the degradation of the planet's natural systems." Since environmental problems are likely to be expressed in a political context, such as the anti-war movement in the U.S.A in the 1960s, stakeholder involvement should lead them to less biased but earth-focused perspectives. It can be assumed that exploring environmental problems require peoples' self-growth in awareness and consciousness regarding the impact of human activities in a holistic framework, understanding our role as a part of the necessary interaction with a natural system.

In terms of active learning about the environment, though the incentive to be engaged in activities varies by each stakeholder, Watarase-yusuichi has significant opportunity to play the role of an ecological platform, not only to learn lessons obtained through the nature information centers located along the west side of the retarding basin, but also play an active role to send information through individual events. The major purpose of the existing centers is to offer nature education materials to visitors, including general information about the history of Watarase, current environmental data on the basin (especially about biodiversity in the wetland), and a miniature landscape of the retarding basin for better understanding of the geography. In addition to the so-called environmental education through the nature centers, there are several experimental sites that were completed in 2007 and conditionally permitted by MLIT for academic purposes, such as examining the effectiveness of topsoil removal for restoration. Several useful data and articles have been published, but the limitation remains in its availability to the public.

In this respect, experience-based learning activities, designed using a bottom-up approach, should be an added value for 
wetlands as an enlightening ecological movement, which reflects the universal paradigm shift regarding the relationship between humans and nature. It should be noted that an open field is conditionally available for environmental study for younger, elementary school children. The several unique environmental events organized by Watarase Mirai Foundation, such as "Let's fish red swamp crayfish" sound appealing from the perspective of environmental study, but the opportunity should be finally extended in such a way that individuals, whether mature or not, express their opinions clearly and openly.

\section{Conclusion}

In considering the complex root of the current "wise use" and the issue of sustainable human use compatible with conservation, we cannot avoid the issue of how to integrate stakeholders in wetland planning and management. The point to be stressed is that stakeholder integration, the importance of which is holistically stressed in IRBM as well as in the Convention itself, was successfully achieved by 2012 in the case of Watarase-yusuichi through the process of designation under the Ramsar Convention, but the incentive to collaborate is now challenged by maintaining interest. The core element of "wise use" of wetlands, as analyzed in the comparison with the Miyagase Dam reservoir with flood control function, lies in the opportunity for individuals to use the wetland as an ecological platform to transmit information actively as an ecologically matured global citizen, not just receive information and learn something through given opportunities. It is critical that new value is created through encouraging individuals to use the wetland as a precious resource and an active ecological learning should be activated to propose ways for ensuring future sustainability.

\section{Acknowledgments}

The present study was conducted as a part of the First Sophia Research Branding Project since 2016.

\section{References}

McCarty, J. (2002). First World political ecology: lessons from the Wise Use movement, Environment and Planning A, 34, 1281-1302. https://doi.org/10.1068/a3526

Ministry of Land, Infrastructure, Transport, and Tourism (2006): The post-project evaluation [PowerPoint slides]. http://www.ktr.mlit.go.jp/honkyoku/kikaku/jigyohyoka/pdf/h17/04siryo/siryo3-2.pdf

Ministry of the Environment. (2015). Ramsar sites in Japan: Conservation and wise use of rich and diverse wetlands. https://www.env.go.jp/en/nature/npr/ramsar_wetland/pamph/ramsarpamphen/RamsarSites_en_web30.pdf

Miyagase Dam Control Office. (2016). Miyagase Sightseeing Spot [Website] http://www.ktr.mlit.go.jp/sagami/sagami00458.html

Nagahama, H. (2012). Direction and task for regional activation around Watarase-yusuichi. Journal of Regional Development Studies, 15, 111-131.

Numata, M. (1973). Conservation and Biology. Tokyo, Kyoritsu Press.

Pinchot, G. (1998). Breaking New Ground: commemorative ed. Washington DC, Island press.

Ramsar Convention. (1971). Article 3.1 [Original articles of Ramsar Convention]. https://www.ramsar.org/sites/default/files/documents/library/original_1971_convention_e.pdf

Ramsar Convention. (1990). Annex to REC. C.4.10 (Rev.) Guidelines for the implementation of the wise use concept. [Annex adopted by the $4^{\text {th }} \mathrm{COP}$ in Montreux, Switzerland].

https://www.ramsar.org/sites/default/files/documents/library/key_rec_4.10e.pdf

Ramsar Convention. (1993). Additional guidance for the implementation of the wise use concept. [Guidance adopted as an annex to Resolution 5.6 of the $5^{\text {th }}$ meeting of the Conference of the Contracting Parties in Kushiro, Japan] http://archive.ramsar.org/cda/en/ramsar-documents-guidelines-additional-guidance-for/main/ramsar/1-31-105\%5E 20915_4000_0_

Ramsar Convention. (2005). Ramsar COP9 Resolution IX.1 Annex A https://www.ramsar.org/sites/default/files/documents/pdf/res/key_res_ix_01_annexa_e.pdf.

Ramsar Convention. (2007). The Ramsar concept of "wise use” Ramsar Information Paper no.7. https://www.ramsar.org/sites/default/files/documents/library/info2007-07-e.pdf.

Ramsar Convention. (2015). Ramsar Fact Sheet 2: Wetlands: Wise use basics on site. https://www.ramsar.org/resources/ramsar-fact-sheets

Smith, G., \& Williams, D. (1999). Ecological education: Extending the definition of environmental education. Australian Journal of Environmental Education, 15, 139-146. https://doi.org/10.1017/S0814062600002718 
Sugiura, M. (2018a). The significance of Watarase-yusuichi from the viewpoint of water sustainability. Paper presented at PAWEES \& INWEPF International Conference 2018 in Nara, Japan.

Sugiura, M. (2018b). Watarase-yusuichi as Integrated River Basin Management. Paper presented at the $12^{\text {th }}$ International Symposium of Ecohydraulics 2018 in Tokyo, Japan.

The editorial committee of Watarase-yusuichi's designation under the Ramsar Convention. (2013). The All Record of the Process toward the Designation of Watarase-yusuichi under the Ramsar Convention. Ustunomiya, Zuiso-sha.

Tonegawa Watershed Community Council for Watarae-yusuichi. (2009). The Watarase-yusuichi Eco-museum Plan. http://sy.studio-web.net/watarase/pdf/tonegawa/t_19.pdf

Tonegawa Watershed Community Council for Watarase-yusuichi. (2005). The New Watarase-yusuichi: toward Eco-museum of Nature and History. Utsunomiya, Zuiso-sha.

UNESCO (The International Hydrological Program of UNESCO and the Network of Asian River Basin Organizations). (2009). Introduction to the IWRM Guidelines at River Basin Level. http://unesdoc.unesco.org/images/0018/001850/185074e.pdf

World Bank. (2006). Integrated river basin management: From concepts to good practice. http://documents.worldbank.org/curated/en/965371468340137430/pdf/411500Intro0to1mgmt0NOTE1101PUBLIC 1.pdf

\section{Copyrights}

Copyright for this article is retained by the author(s), with first publication rights granted to the journal.

This is an open-access article distributed under the terms and conditions of the Creative Commons Attribution license which permits unrestricted use, distribution, and reproduction in any medium, provided the original work is properly cited. 